\title{
Potential of Natural Antimicrobials for the Production of Minimally Processed Fresh-Cut Apples
}

Lorenzo Siroli' ${ }^{1}$, Francesca Patrignani ${ }^{1}$, Diana I. Serrazanetti ${ }^{2}$, Giulia Tabanelli ${ }^{2}$, Chiara Montanari ${ }^{2}$, Silvia Tappi ${ }^{1}$, Pietro Rocculi ${ }^{1}$, Fausto Gardini ${ }^{1}$, Rosalba Lanciotti ${ }^{1 *}$

${ }^{1}$ Department of Agricultural and Food Sciences, Alma Mater Studiorum, University of Bologna, Piazza Goidanich 60, 47521 Cesena, Italy

${ }^{2}$ Interdepartmental Center for Industrial Agri-Food Research, University of Bologna, Piazza Goidanich 60, 47521 Cesena (FC), Italy

\begin{abstract}
Background: Minimally processed fruit are susceptible to microbial spoilage and loss of sensory quality. In this experimental work, in order to increase the shelf-life and to maintain quality parameter (texture and colour) of sliced apples (Malus communis, var. Golden delicious), the use of natural antimicrobials was proposed.
\end{abstract}

Materials and methods: Natural antimicrobials were purposed to produce fresh-cut apples. Hexanal, citral, and combinations of hexanal+citral, citron essential oil+carvacrol, citral+2-(E)-hexenal, citral+citron essential oil and hexanal+2- $(E)$-hexenal were used in dipping step. After treatment, sample were stored at $6^{\circ} \mathrm{C}$ in ordinary atmosphere. During storage, yeast and lactic acid bacteria were monitored. Also volatile and electronic nose profiles, colour and texture analyses were considered. The samples were compared with a control (apples dipped in ascorbic and citric acid solution)

Results: Yeast cell loads showed that natural antimicrobials changed naturally occurring yeast growth parameters. The combination of citron+carvacrol prolonged the yeast lag phase of $6 \mathrm{~d}$ comparing with control, while citral and hexanal $+2-(E)-$ hexenal decreased the maximum reached yeast cell load and growth rate, respectively. After $8 \mathrm{~d}$, samples with hexanal+2-(E)hexenal and citral showed equivalent or even better quality attributes compared to the controls, suggesting that this approach is a useful tool for fresh-cut apple production.

Highlight: Natural antimicrobial can be useful for the dipping of minimally processed apples Citral and hexanal+2-(E)-hexenal prolonged the apples shelf-life.

Apples treated with Citral and hexanal+2-(E)-hexenal had good quality attributes.

Keywords: Citron essential oil; Fresh-cut apples; Natural antimicrobials; Quality parameters; Shelf-life

\section{Introduction}

Minimally processed fruits are among the most requested products because they provide high nutritional value while maintaining their freshness appeal and they do not generally contain preservatives or antimicrobial substances. However, the raw materials are frequently in contact with soil, animals, insects or humans during growth and harvesting [1]; therefore by the time they reach the manufacturing the majority of fresh produces retain microbial populations of 4-6 $\log \mathrm{CFU}$ $\mathrm{g}^{-1}$. For this, the safety of fresh-cut fruit is significantly affected by the presence of microorganisms on raw fruit surface [2]. Also preparation steps during processing such as peeling, cutting or slicing favour the microbial growth on the final product $[3,4]$. The presence on fresh fruit and related fresh-cut products of pathogenic bacteria belonging to Listeria monocytogenes, Escherichia coli, Salmonella spp., Yersinia enterocolitica, Aeromonas hydrophila and Staphylococcus aureus is well documented [5,6], so fresh fruit productions have been incriminated in several outbreaks caused by these pathogenic species. On the other hand, pathogens eventually introduced during the production chain may remain until the product consumption due to the lacking of treatments able to inactivate the microbial cells. Actually the safety and the shelflife of the products is generally based on the cold chain maintenance during storage and the most used disinfectant agent of the raw material is chlorine $[7,8]$. Currently, there is increasing consumer pressure to replace chemically synthesized antimicrobials with natural alternatives in order to ensure food safety and maintain quality of fresh-cut fruit [9-13]. Plants and plant products can represent a source of natural antimicrobials for this purpose; moreover they are characterized by a wide range of volatile compounds, some of which are important flavour quality factors [14]. Among plant derivatives, essential oils have been investigated for their antimicrobial activity against many microorganisms, including spoilage and pathogenic species [15]. A wide literature is focused on the antimicrobial activity of citrus oils [16-18]. The action of their single constituents has been studied to identify their cell targets and the most active molecules, and to balance their intrinsic variability [19]. Particularly citral (3,7-dimethyl-2-7octadienal), an acyclic $\alpha, \beta$-unsaturated monoterpene aldehyde, is an isoprenoid compound with 2 isomers, geranial and neral, naturally occurring in citrus essential oils and characterized by a broad spectrum antimicrobial activity [20]. Belletti et al. [21] showed that, used at concentration compatible with the sensorial properties of the products, citral and citron essential oil, were able to prolong the microbial shelf life of the fruit-based salads in syrup.

The antimicrobial activity against spoilage species of hexanal and 2-(E)-hexenal, which are components of the aroma of many fruits and vegetables, was already tested in model [22] as well as in real systems

*Corresponding author: Rosalba Lanciotti, Department of Agricultural and Food Sciences, Alma Mater Studiorum, University of Bologna, Piazza Goidanich 60, 47521 Cesena, Italy, Tel: +39 0547 338132; E-mail: rosalba.lanciotti@unibo.it

Received November 26, 2014; Accepted December 12, 2014; Published January 08, 2015

Citation: Siroli L, Patrignani F, Serrazanetti DI, Tabanelli G, Montanari C, et al. (2015) Potential of Natural Antimicrobials for the Production of Minimally Processed Fresh-Cut Apples. J Food Process Technol 6: 415. doi:10.4172/21577110.1000415

Copyright: ( 2015 Siroli L, et al. This is an open-access article distributed under the terms of the Creative Commons Attribution License, which permits unrestricted use, distribution, and reproduction in any medium, provided the original author and source are credited. 
Citation: Siroli L, Patrignani F, Serrazanetti DI, Tabanelli G, Montanari C, et al. (2015) Potential of Natural Antimicrobials for the Production of Minimally Processed Fresh-Cut Apples. J Food Process Technol 6: 415. doi:10.4172/2157-7110.1000415

[23]. Hexanal, 2-(E)-hexenal, and hexyl acetate prolonged the shelf-life of fresh-cut fruit [24].

Also Siroli et al. [8] proved that the use of natural antimicrobials, combined with modified atmosphere packaging (MAP), were effective in the shelf-life prolongation of minimally sliced apples. Specific combinations of natural antimicrobials resulted in products having a shelf-life of $35 \mathrm{~d}$. However, some Authors report that the use of MAP can produce some flavor and visual and/or by microbial outgrowth defects. For example, exposure to elevated $\mathrm{CO}_{2}$ levels (10-20\%) may result in the suppression of various metabolic processes [25]. Also the lack of $\mathrm{O}_{2}$ can provoke off-flavour development in fresh-cut products inducing a shift from an aerobic towards an anaerobic atmosphere. In addition the packaging in MAP is perceived by the producers as an additional cost.

In this direction, the principal aim of this work was to evaluate the effects of dipping treatments with different concentrations of hexanal, (E)-2-hexenal, citral, carvacrol and citron Essential Oil (EO), alone or in combination, on the shelf-life of sliced fresh-cut apple stored at $6^{\circ} \mathrm{C}$ in ordinary atmosphere. Before using in real system, the determination of citron EO composition, the Minimum Inhibitory Concentration (MIC) and minimum bactericidal concentration (MBC) values of the chosen substances against the most frequent pathogenic species in this kind of products (L. monocytogenes, E. coli, Salmonella spp.) were performed. The influence of the tested substances on microbial evolution, colour and texture changes, as well as on aroma compounds and electronic nose profiles were determined during maximum $21 \mathrm{~d}$ of storage at $6^{\circ} \mathrm{C}$ in ordinary atmosphere.

\section{Materials and Methods}

\section{Natural antimicrobials}

Citron essential oil (EO), whose composition was reported by Belletti et al. [16] was obtained from Flora s.r.l. (Pisa, Italy), while all the other compounds (Hexanal, 2-(E)-hexenal, Citral and Carvacrol) were purchased from Sigma-Aldrich (Milano, Italy). The EO and the used natural antimicrobial were selected both for their antimicrobial activity and for the impact on organoleptic properties of the product.

\section{Minimum Inhibitory Concentration (MIC) and Minimum Bactericidal Concentration (MBC) determination}

For the determination of MIC values, $150 \mu \mathrm{L}$ of $\mathrm{BHI}$ broth inoculated at three different levels $\left(2,4\right.$ or $\left.6 \log \mathrm{CFU} \mathrm{mL}{ }^{-1}\right)$ of the tested pathogens (Listeria monocytogenes Scott A, Salmonella enteritidis E5, Escherichia coli 555, S. aureus F1, Bacillus cereus SV90) were added to $200 \mu \mathrm{L}$ microtiter wells (Corning Incorporated, NY, USA). $15 \mu \mathrm{L}$ of the tested EO or natural antimicrobials, properly diluted in Brain Heart Infusion (BHI, Oxoid Ltd., Basingstoke, Hampshire, United Kingdom) broth and conveyed through $96 \%$ ethanol (VWR international, PROLABO, France) were added to each well in order to obtain the required concentration of each compound in the final volume $(200 \mu \mathrm{L})$, and with a constant amount of ethanol ( $1 \% \mathrm{v} / \mathrm{v}$ in wells). Microtiter plates were incubated at $37^{\circ} \mathrm{C}$ and checked after 24 and $48 \mathrm{~h}$. The MBC were determined by spotting $10 \mu \mathrm{L}$ of each well after $48 \mathrm{~h}$, onto BHI agar plates [26].

MIC was defined as the lowest concentration of the compound preventing visible growth of the inoculated cells after $24 \mathrm{~h}$ (MIC $24 \mathrm{~h}$ ) or $48 \mathrm{~h}$ (MIC $48 \mathrm{~h}$ ). The MBC was defined as the lowest concentration of the compound that caused the death of the inoculated cells, corresponding to no growth after $24 \mathrm{~h}$ of incubation at $37^{\circ} \mathrm{C}$ of a $10 \mu \mathrm{L}$ spot plated onto BHI agar.

\section{Preparation of fresh-cut apple slices}

Apples (Golden delicious) were purchased from a local retailer and conditioned at $10^{\circ} \mathrm{C}$ for three hours before the preparation. Subsequently the fruits were washed with running water at $13^{\circ} \mathrm{C}$ for $2 \mathrm{~min}$, dried with blotting paper and peeled and sliced into cubes of roughly $1.5 \mathrm{~cm}^{3}$ by hand with a sharp knife. EO and natural antimicrobials were added to an aqueous solution at $1 \%$ citric acid $+0.5 \%$ ascorbic acid. Eight different dipping solutions at a temperature of $13^{\circ} \mathrm{C}$ were prepared with running water and a concentration of $250 \mathrm{mg} \mathrm{L}^{-1}$ of citral and hexanal alone; $125+125 \mathrm{mg} \mathrm{L}^{-1}$ for the combinations of citral+hexanal, citral+2(E)-hexenal, hexanal+2-(E)-hexenal, citral+citron EO; 200+50 $\mathrm{mg} \mathrm{L}^{-1}$ for the combination of citron EO+carvacrol. Natural antimicrobials were conveyed through $1 \%(\mathrm{v} / \mathrm{v})$ of ethanol. Control apple slices were subjected to the dipping treatment without the supplementation of natural antimicrobials. Apple slices were dipped and gently agitated in the solutions for 2 min with a ratio apples:water of 1:10 (w/v). After the treatment, apples were dried with paper and packaged into $50 \mu \mathrm{m}$ thick BOPP bags $\left(\mathrm{PCO}_{2}\right.$ at $22^{\circ} \mathrm{C}: 2720\left(\mathrm{~cm}^{3} / \mathrm{m}^{2} / \mathrm{d}\right), \mathrm{PO}_{2}$ at $22^{\circ} \mathrm{C}: 970$ $\left.\left(\mathrm{cm}^{3} / \mathrm{m}^{2} / \mathrm{d}\right)\right)$ inserting $50 \mathrm{~g}$ of product with a ratio apples:headspace of $1: 1$. The packages have been stored at $6^{\circ} \mathrm{C}$ and analysed during $21 \mathrm{~d}$ of storage.

\section{Microbiological analyses}

The evolution over time of lactic acid bacteria and yeasts was evaluated during storage by plate counting, respectively on Man Rogosa and Sharpe Agar (MRS, Oxoid Ltd., Basingstoke, Hampshire, United Kingdom) and Sabouraud Dextrose Agar (SAB, Oxoid Ltd., Basingstoke, Hampshire, United Kingdom). Microbiological analyses were performed after stomacher and properly dilution of the samples into sterile physiological water (diluted into $90 \mathrm{~mL}$ of physiological water $(0.9 \%(\mathrm{w} / \mathrm{v}) \mathrm{NaCl})$. The analyses were performed immediately after the treatments and after 2, 3, 7, 10, 14 and $21 \mathrm{~d}$ of storage.

\section{Volatile molecule profiles and electronic nose analyses}

Apple packages were used for headspace volatile compound analysis by GC/MS-SPME technique. For each treatment condition the samples were analyzed immediately after the treatments and after 3 and $10 \mathrm{~d}$ of storage. The samples were conditioned $30 \mathrm{~min}$ at $37^{\circ} \mathrm{C}$; after that for fiber and gas-chromatographyc conditions, the method reported by Patrignani et al. [26] was adopted.

Compounds were identified by the use of the Agilent HewlettPackard NIST 98 mass spectral database.

Electronic nose (EN) analyses have been performed on the headspace of $40 \mathrm{~mL}$ vials, sealed by a lid with a PTFE/silicon septa, containing $5 \mathrm{~g}$ of apples. EN evaluations were carried out immediately after the treatments and after 3 and $10 \mathrm{~d}$ of storage. Sample vials were conditioned before the analysis for $30 \mathrm{~min}$ at $37^{\circ} \mathrm{C}$. Determinations were performed with a commercial portable electric nose PEN2 (Airsense Analytics, Milano, Italy) composed of an array of 10 temperaturemoderated metal-oxide sensors (MOS), a sampling system, a data acquisition system, and a data processing system according to the method reported by Sado et al. [27].

\section{Physical analyses: colour and texture}

Surface colour was measured using a colour-spectrophotometer mod. Colorflex (Hunterlab, USA). Colour was measured using the 
CIELab scale and Illuminant D65. The instrument was calibrated with a white tile $\left(\mathrm{L}^{\star} 98.03, \mathrm{a}^{\star}-0.23, \mathrm{~b}^{\star} 2,05\right)$ before the measurements. Results were expressed as $\mathrm{L}^{*}$ (luminosity) and $\mathrm{a}^{*}$ (red index); numerical values of $\mathrm{a}^{\star}$ and $\mathrm{b}^{\star}$ were converted into hue angle $\left(\mathrm{h}^{\circ}\right)$, according to the following equations [28]

$$
h^{\circ}=\frac{\tan ^{-1}\left(b^{*} / a^{*}\right)}{2 \pi} \cdot 360
$$

At each storage time, 21 readings were obtained for each sample from the seven packages, measuring three slices for each package.

Firmness measurement was performed at room temperature $(20$ $\pm 2^{\circ} \mathrm{C}$ ), about $1 \mathrm{~h}$ after removing the samples from the refrigerated room. Penetration tests were carried out by measuring the maximum force registered during penetration of a $6 \mathrm{~mm}$ diameter stainless steel cylinder for $6 \mathrm{~mm}$ into the apple slice tissue, using a Texture analyser mod. HD500 (Stable Micro Systems, Surrey, UK) equipped with a $50 \mathrm{~kg}$ load cell. Test speed was $0.5 \mathrm{mms}^{-1}$ and data were expressed in kilograms $(\mathrm{kg})$. At each storage time, 21 tests were performed for each sample from the seven packages, measuring three slices for each package.

\section{Statistical analysis}

All the data obtained are the meaning of three repetitions.

The yeast cell load data were modelled according to the Gompertz equation, modified by Zwietering, Jongenburger, Rombouts and Van 'T Riet [29]:

$$
y=K+A \cdot \exp \left\{-\exp \left[\left(\mu_{\max } \cdot e / A\right) \mathrm{x}(\lambda-t)+1\right]\right\}
$$

where

$\mathrm{k}$ : initial level of yeast $\left(\log \mathrm{CFU} \mathrm{ml}^{-1}\right)$;

A: maximum cellular density increase with respect to the initial cell load (k) (log CFU ml-1);

$\mu$ max: maximum specific growth rate $\left(\log (\mathrm{CFU} / \mathrm{ml})\right.$ days $\left.^{-1}\right)$;

$\lambda$ : latency time (lag time) (days);

$\mathrm{t}$ : is the time

The experimental data were modelled through the Non Linear Regression Procedure of the statistic package Statistica for Windows (Statsoft, Tulsa, OK).

The spoilage threshold $\left(6 \log \mathrm{CFU} \mathrm{g^{-1 }}\right)$ can be defined as the sum of $\mathrm{k}$, corresponding to the initial level of yeast after sample packaging, and $\mathrm{A}$, corresponding to the maximum cellular density increase with respect to initial cell load $(\mathrm{k})$.

For each sample, microbiological, volatiles and EN data were the average of three different samples of three independent experiments.

The significance of the differences among the Gompertz parameters in relation to the dipping conditions, was evaluated using ANOVA followed by LSD test at $p<0.01$. The same statistical approach was employed to evaluate the significance of the differences recorded in the time (d) necessary to reach the cell load of $6.0 \log \mathrm{CFU} \mathrm{mL}{ }^{-1}$, chosen as spoilage threshold.

The quantitative data obtained from metabolites determinations and EN were used to build up a single matrix, which was submitted to a two-way hierarchical clustering analysis. A heat map, visualizing metabolite concentrations, was obtained; in the map the values are represented by cells coloured according to the Z-scores, where:

$\mathrm{Z}=$ (observed value-average)/standard deviation [30].

\section{Results and Discussion}

\section{Minimum inhibitory concentration (MIC) and minimum bactericidal concentration (MBC) evaluation}

The MICs and the MBCs of the citral, hexanal, 2-(E)-hexenal, citron EO and carvacrol against Listeria monocytogenes Scott A, Escherichia coli 555, Salmonella enteritidis E5, Staphylococcus aureus F1, and Bacillus cereus SV 90 were assessed after incubation at $37^{\circ} \mathrm{C}$, with three levels of the target microorganisms (Table 1). Pronounced differences in the MICs and MBCs were observed in relation to the substances, the species and the inoculum level considered. Citron oil exhibited the lowest antimicrobial activity with respect to the other molecules studied, showing, with few exceptions, MIC and MCB values higher than $1000 \mathrm{mg} \mathrm{L}^{-1}$ independently from the species and the inoculation level. Only L. monocytogenes and S. aureus inoculated at levels of $10^{2}$ CFU mL ${ }^{-1}$ had MIC values of 500 and $800 \mathrm{mg} \mathrm{L}^{-1}$, respectively. Belletti et al. [21] showed a reduced effects of this oil used at a concentration ranging between 300 and $600 \mathrm{mg} \mathrm{L}^{-1}$ on Gram-negative species, such as $S$. enteritidis and E. coli deliberately inoculated in salad fruit in syrup, but a marked inhibition toward the Gram-positive pathogen $L$. monocytogenes.

Citral showed a low antimicrobial effectiveness against the Gram-negative species considered, being the MIC values always higher than $1500 \mathrm{mg} \mathrm{L}^{-1}$, independently on the inoculation level. On the contrary, Gram positive species had MIC values ranging between 250 and $700 \mathrm{mg} \mathrm{L}^{-1}$ as a function of the initial inoculation level. The effect of inoculation level is particularly evident for B. cereus and $S$. aureus, whose MICs and MCBs decreased from 700 and $550 \mathrm{mg} \mathrm{L}^{-1}$ to 250 and $300 \mathrm{mg} \mathrm{L}^{-1}$ in cultures of $10^{6}$ and $10^{2} \mathrm{CFU} \mathrm{mL} \mathrm{mL}^{-1}$ respectively. The needed concentrations to obtain MICs and MBCs at high cell levels were in these cases about doubled compared with those needed to reach the same result at the lower cell level. The influence of the initial inoculum on MICs and MBCs was evident also in the presence of hexanal and 2-(E)-hexenal showing highest efficacy against E. coli and $S$. enteritidis while they were quite ineffective against the other target microorganisms. This different response of Gram-positive and Gram-negative bacteria is already reported in the literature. Gramnegative bacteria are generally more resistant to many compounds due to the outer membrane, which acts as an efficient permeability barrier against macromolecules and hydrophobic substances as well as to the high content in cyclopropane fatty acids of the inner membrane [31]. If enough hydrophilic, low molecular mass molecules seem to be more efficient in passing through these barriers and they may have access, throughout porin proteins, to the deeper parts of Gramnegative bacteria without any alteration to the permeability of the outer membrane. On the contrary, carvacrol showed the highest efficacy both against considered Gram-positive and Gram-negative bacteria having MIC values ranging between 175 and $200 \mathrm{mg} \mathrm{L}^{-1}$ for S. Enteritidis and E. coli and 175-275 $\mathrm{mg} \mathrm{L}^{-1}$ for L. monocytogenes, B. cereus and S. aureus. The results showed values of MIC and MCB relatively high due to the optimal microbial growth conditions, and to the high inoculation levels used and not compatible with the product sensorial properties. However, for apple slices treatment, concentrations significantly lower with respect to MIC values were used, taking into consideration the real contamination level (pathogens were absent in $25 \mathrm{~g}$ of products) of the product with pathogenic species, the more stringent conditions of the 
Citation: Siroli L, Patrignani F, Serrazanetti DI, Tabanelli G, Montanari C, et al. (2015) Potential of Natural Antimicrobials for the Production of Minimally Processed Fresh-Cut Apples. J Food Process Technol 6: 415. doi:10.4172/2157-7110.1000415

Page 4 of 9

\begin{tabular}{|c|c|c|c|c|c|c|c|c|c|}
\hline \multicolumn{10}{|c|}{ Listeria monocytogenes } \\
\hline $\begin{array}{l}\text { Cells } \\
\text { concentration }\end{array}$ & $6 \log \mathrm{CFU} \mathrm{mL}^{-1}$ & $6 \log \mathrm{CFU} \mathrm{mL}{ }^{-1}$ & $6 \log \mathrm{CFU} \mathrm{mL}^{-1}$ & $4 \log \mathrm{CFU} \mathrm{mL}^{-1}$ & $4 \log \mathrm{CFU} \mathrm{mL}^{-1}$ & $4 \log \mathrm{CFU} \mathrm{mL}^{-1}$ & $2 \log \mathrm{CFU} \mathrm{mL}^{-1}$ & $2 \log \mathrm{CFU} \mathrm{mL}^{-1}$ & $2 \log \mathrm{CFU} \mathrm{mL}^{-1}$ \\
\hline MIC/MBC & MIC $24 \mathrm{~h}\left(\mathrm{mg} \mathrm{L}^{-1}\right)$ & MIC 48h $\left(\mathrm{mg} \mathrm{L}^{-1}\right)$ & $\mathrm{MBC}\left(\mathrm{mg} \mathrm{L}^{-1}\right)$ & $\begin{array}{l}\text { MIC 24h (mg } \\
\left.L^{-1}\right)\end{array}$ & MIC 48h $\left(\mathrm{mg} \mathrm{L}^{-1}\right)$ & $\mathrm{MBC}\left(\mathrm{mg} \mathrm{L}^{-1}\right)$ & MIC 24h (mg L-1) & MIC 48h (mg L-1) & $\mathrm{MBC}\left(\mathrm{mg} \mathrm{L}^{-1}\right)$ \\
\hline Citral & 350 & 475 & 500 & 325 & 425 & 425 & 250 & 300 & 325 \\
\hline 2-(E)-hexenal & 1250 & 1400 & $>1500$ & 1250 & 1400 & $>1500$ & 850 & 1300 & 1400 \\
\hline Hexanal & $>1500$ & $>1500$ & $>1500$ & 1500 & $>1500$ & $>1500$ & 1350 & $>1500$ & $>1500$ \\
\hline Citron oil & $>1200$ & $>1200$ & $>1200$ & $>1000$ & $>1000$ & $>1000$ & 500 & $>1000$ & $>1000$ \\
\hline Carvacrol & 175 & 200 & 225 & 150 & 175 & 200 & 100 & 175 & 200 \\
\hline \multicolumn{10}{|c|}{ Escherichia coli } \\
\hline $\begin{array}{l}\text { Cells } \\
\text { concentration }\end{array}$ & $6 \log \mathrm{CFU} \mathrm{mL}^{-1}$ & $6 \log \mathrm{CFU} \mathrm{mL}^{-1}$ & $6 \log \mathrm{CFU} \mathrm{mL}^{-1}$ & $4 \log \mathrm{CFU} \mathrm{mL} \mathrm{m}^{-1}$ & $4 \log$ CFU mL ${ }^{-1}$ & $4 \log \mathrm{CFU} \mathrm{mL}^{-1}$ & $2 \log C F U \mathrm{~mL}^{-1}$ & $2 \log$ CFU mL-1 & $2 \log \mathrm{CFU} \mathrm{mL}^{-1}$ \\
\hline MIC/MBC & $\underset{\left.L^{-1}\right)}{\operatorname{MIC} 24 h(m g}$ & MIC $48 \mathrm{~h}\left(\mathrm{mg} \mathrm{L}^{-1}\right)$ & $\mathrm{MBC}\left(\mathrm{mg} \mathrm{L}^{-1}\right)$ & $\begin{array}{l}\text { MIC } 24 \mathrm{~h}(\mathrm{mg} \\
\left.\mathrm{L}^{-1}\right)\end{array}$ & MIC $48 \mathrm{~h}\left(\mathrm{mg} \mathrm{L}^{-1}\right)$ & $\mathrm{MBC}\left(\mathrm{mg} \mathrm{L}^{-1}\right)$ & MIC $24 \mathrm{~h}\left(\mathrm{mg} \mathrm{L}^{-1}\right)$ & MIC 48h (mg L-1) & $\mathrm{MBC}\left(\mathrm{mg} \mathrm{L}^{-1}\right)$ \\
\hline Citral & $>1500$ & $>1500$ & $>1500$ & $>1500$ & $>1500$ & $>1500$ & $>1500$ & $>1500$ & $>1500$ \\
\hline 2-(E)-hexenal & 525 & 600 & 650 & 500 & 575 & 575 & 500 & 525 & 525 \\
\hline Hexanal & $>1500$ & $>1500$ & $>1500$ & 1050 & $>1500$ & $>1500$ & 700 & 1200 & $>1200$ \\
\hline Citron oil & $>1200$ & $>1200$ & $>1200$ & $>1200$ & $>1200$ & $>1200$ & $>1000$ & $>1000$ & $>1000$ \\
\hline Carvacrol & 200 & 200 & 225 & 200 & 200 & 200 & 200 & 200 & 200 \\
\hline \multicolumn{10}{|c|}{ Salmonella enteritidis } \\
\hline $\begin{array}{l}\text { Cells } \\
\text { concentration }\end{array}$ & $6 \log \mathrm{CFU} \mathrm{mL}^{-1}$ & $6 \log \mathrm{CFU} \mathrm{mL}{ }^{-1}$ & $6 \log \mathrm{CFU} \mathrm{mL} \mathrm{m}^{-1}$ & $4 \log \mathrm{CFU} \mathrm{mL}^{-1}$ & $4 \log \mathrm{CFU} \mathrm{mL}-1$ & $4 \log \mathrm{CFU} \mathrm{mL}^{-1}$ & $2 \log \mathrm{CFU} \mathrm{mL}^{-1}$ & $2 \log \mathrm{CFU} \mathrm{mL}^{-1}$ & $2 \log \mathrm{CFU} \mathrm{mL}^{-1}$ \\
\hline MIC/MBC & $\mathrm{MIC}_{\left.\mathrm{L}^{-1}\right)} 24 \mathrm{~h}(\mathrm{mg}$ & $\operatorname{MIC} 48 \mathrm{~h}\left(\mathrm{mg} \mathrm{L}^{-1}\right)$ & $\mathrm{MBC}\left(\mathrm{mg} \mathrm{L}^{-1}\right)$ & $\begin{array}{l}\mathrm{MIC} 24 \mathrm{~h}(\mathrm{mg} \\
\left.\mathrm{L}^{-1}\right)\end{array}$ & MIC $48 \mathrm{~h}\left(\mathrm{mg} \mathrm{L}^{-1}\right)$ & $\mathrm{MBC}\left(\mathrm{mg} \mathrm{L}^{-1}\right)$ & MIC 24h $\left(\mathrm{mg} \mathrm{L}^{-1}\right)$ & $\mathrm{MIC}_{\left.\mathrm{L}^{-1}\right)} 48 \mathrm{~h}(\mathrm{mg}$ & $\mathrm{MBC}\left(\mathrm{mg} \mathrm{L}^{-1}\right)$ \\
\hline Citral & $>1500$ & $>1500$ & $>1500$ & $>1500$ & $>1500$ & $>1500$ & $>1500$ & $>1500$ & $>1500$ \\
\hline 2-(E)-hexenal & $>1500$ & $>1500$ & $>1500$ & $>1500$ & $>1500$ & $>1500$ & 800 & 1300 & 1500 \\
\hline Hexanal & $>1500$ & $>1500$ & $>1500$ & 1050 & $>1500$ & $>1500$ & $>1500$ & $>1500$ & $>1500$ \\
\hline Citron oil & $>1200$ & $>1200$ & $>1200$ & $>1200$ & $>1200$ & $>1200$ & $>1000$ & $>1000$ & $>1000$ \\
\hline Carvacrol & 200 & 200 & 250 & 175 & 175 & 200 & 175 & 175 & 200 \\
\hline \multicolumn{10}{|c|}{ Bacillus cereus } \\
\hline $\begin{array}{l}\text { Cells } \\
\text { concentration }\end{array}$ & $6 \log \mathrm{CFU} \mathrm{mL}^{-1}$ & $6 \log \mathrm{CFU} \mathrm{mL}^{-1}$ & $6 \log \mathrm{CFU} \mathrm{mL}^{-1}$ & $4 \log \mathrm{CFU} \mathrm{mL}-1$ & $4 \log \mathrm{CFU} \mathrm{mL}^{-1}$ & $\begin{array}{l}4 \log \mathrm{CFU} \\
\mathrm{mL}^{-1}\end{array}$ & $2 \log \mathrm{CFU} \mathrm{mL}^{-1}$ & $2 \log \mathrm{CFU} \mathrm{mL}-1$ & $2 \log \mathrm{CFU} \mathrm{mL}^{-1}$ \\
\hline MIC/MBC & $\underset{\left.L^{-1}\right)}{\operatorname{MIC} 24 h(m g}$ & MIC 48h $\left(\mathrm{mg} \mathrm{L}^{-1}\right)$ & $\mathrm{MBC}\left(\mathrm{mg} \mathrm{L}^{-1}\right)$ & $\begin{array}{l}\text { MIC } 24 h(m g \\
\left.L^{-1}\right)\end{array}$ & MIC $48 \mathrm{~h}\left(\mathrm{mg} \mathrm{L}^{-1}\right)$ & $\operatorname{MBC}\left(\mathrm{mg} \mathrm{L}^{-1}\right)$ & MIC 24h $\left(\mathrm{mg} \mathrm{L}^{-1}\right)$ & $\begin{array}{l}\mathrm{MIC} 48 \mathrm{~h}(\mathrm{mg} \\
\left.\mathrm{L}^{-1}\right)\end{array}$ & $\mathrm{MBC}\left(\mathrm{mg} \mathrm{L}^{-1}\right)$ \\
\hline Citral & 300 & $>650$ & $>650$ & 300 & 350 & 350 & 300 & 300 & 300 \\
\hline 2-(E)-hexenal & 1200 & 1350 & $>1400$ & 1200 & 1350 & $>1400$ & 800 & 1250 & 1300 \\
\hline Hexanal & $>1500$ & $>1500$ & $>1500$ & 1500 & $>1500$ & $>1500$ & 1350 & $>1500$ & $>1500$ \\
\hline Citron oil & $>2000$ & $>2000$ & $>2000$ & $>2000$ & $>2000$ & $>2000$ & $>2000$ & $>2000$ & $>2000$ \\
\hline Carvacrol & 175 & 175 & 200 & 150 & 175 & 175 & 150 & 150 & 150 \\
\hline \multicolumn{10}{|c|}{ Staphylococcus aureus } \\
\hline $\begin{array}{l}\text { Cells } \\
\text { concentration }\end{array}$ & $6 \log \mathrm{CFU} \mathrm{mL}^{-1}$ & $6 \log \mathrm{CFU} \mathrm{mL}^{-1}$ & $6 \log \mathrm{CFU} \mathrm{mL} \mathrm{m}^{-1}$ & $4 \log \mathrm{CFU} \mathrm{mL} \mathrm{m}^{-1}$ & $4 \log \mathrm{CFU} \mathrm{mL}^{-1}$ & $\begin{array}{l}4 \log \mathrm{CFU} \\
\mathrm{mL}^{-1}\end{array}$ & $2 \log \mathrm{CFU} \mathrm{mL}^{-1}$ & $2 \log \mathrm{CFU} \mathrm{mL}^{-1}$ & $2 \log \mathrm{CFU} \mathrm{mL}^{-1}$ \\
\hline MIC/MBC & $\begin{array}{l}\text { MIC } 24 h(m g \\
\left.L^{-1}\right)\end{array}$ & MIC $48 \mathrm{~h}\left(\mathrm{mg} \mathrm{L}^{-1}\right)$ & $\mathrm{MBC}\left(\mathrm{mg} \mathrm{L}^{-1}\right)$ & $\begin{array}{l}\text { MIC } 24 \mathrm{~h}(\mathrm{mg} \\
\left.\mathrm{L}^{-1}\right)\end{array}$ & MIC 48h (mg L-1) & $\mathrm{MBC}\left(\mathrm{mg} \mathrm{L}^{-1}\right)$ & MIC $24 \mathrm{~h}\left(\mathrm{mg} \mathrm{L}^{-1}\right)$ & $\begin{array}{l}\text { MIC } 48 \mathrm{~h}(\mathrm{mg} \\
\left.\mathrm{L}^{-1}\right)\end{array}$ & $\operatorname{MBC}\left(\mathrm{mg} \mathrm{L}^{-1}\right)$ \\
\hline Citral & 500 & 550 & 550 & 450 & 500 & 500 & 250 & 250 & 250 \\
\hline 2-(E)-hexenal & 1200 & 1400 & $>1500$ & 1300 & 1400 & $>1500$ & 900 & 1300 & 1400 \\
\hline Hexanal & $>1500$ & $>1500$ & $>1500$ & 1500 & $>1500$ & $>1500$ & 1400 & $>1500$ & $>1500$ \\
\hline Citron oil & $>1200$ & $>1200$ & $>1200$ & $>1000$ & $>1000$ & $>1000$ & 800 & $>1000$ & $>1000$ \\
\hline Carvacrol & 275 & 275 & 275 & 200 & 250 & 250 & 150 & 200 & 200 \\
\hline
\end{tabular}

Table 1: Minimum inhibitory concentration (MIC) and minimum bactericidal concentration (MBC) of citral, 2-(E)-hexenal, hexanal, citron oil and carvacrol against $L$. monocytogenes, E. coli, S. enteritidis, B. cereus and S. aureus in relation to the inoculum level.

real system with respect to the model one used for MIC determination, and the product sensorial acceptance.

\section{Effects of citron EO and natural antimicrobials on the shelf- life of apple slices}

During refrigerated storage, the growth of Lactic Acid Bacteria $(\mathrm{LAB})$ and yeasts was evaluated because they are the main microbial groups involved in fresh-cut fruit spoilage. In fact for these commodities the $\mathrm{pH}$ value, the sugar content and the $\mathrm{C} / \mathrm{N}$ ratio favour the growth of LAB, yeast and moulds. However, the increased respiration rate of the fresh-cut fruit tissue caused by endogenous wounding response rapidly consume a great part of the oxygen present in the packages, creating an environment not suitable for the growth of aerobic moulds. The Gompertz parameters recorded for yeasts are shown in Table 2. Immediately after apple packaging, the yeast levels were under the detection limit, independently of the presence of the test compounds; for this reason $\mathrm{K}$ values were not reported. Yeasts showed a significant $(\mathrm{p}<0.01)$ higher growth rate in the control sample compared to the other samples, reaching cell loads of $6.0 \log \mathrm{CFU} \mathrm{g}{ }^{-1}$ after about $12 \mathrm{~d}$. This level of cell load can be considered as an acceptability threshold, because it corresponds to the beginning of a perceivable spoilage [32] 


\begin{tabular}{|c|c|c|c|c|c|}
\hline Samples & A & $\mu_{\max }$ & $\lambda$ & $\mathbf{R}$ & Time (days) \\
\hline Control a & 7.55 & 0.97 & 5.04 & 0.99 & 12.12 \\
\hline Citron oil + citral ${ }^{b}$ & 6.54 & 0.96 & 6.87 & 0.99 & 15.79 \\
\hline Hexanal + 2-(E)-hexenal c & 5.40 & 0.43 & 3.40 & 0.99 & $-i$ \\
\hline Citral $^{d}$ & 5.17 & 0.72 & 7.00 & 0.99 & - \\
\hline Citral + Hexanal e & 8.30 & 0.68 & 7.53 & 0.99 & 17.17 \\
\hline Hexanal $^{f}$ & 6.97 & 0.51 & 7.94 & 0.99 & 22.55 \\
\hline Citral + 2-(E)-hexenal ${ }^{g}$ & 7.62 & 0.51 & 8.56 & 0.99 & 21.97 \\
\hline Citron oil + Carvacrol ${ }^{\text {h }}$ & 7.74 & 1.14 & 10.90 & 0.99 & 16.83 \\
\hline
\end{tabular}

a Control was washed only with dipping solution ( $1 \%$ citric acid $+0.5 \%$ ascorbic acid)

b Concentration employed $125 \mathrm{mg} \mathrm{L}^{-1}$ each.

c Concentration employed $125 \mathrm{mg} \mathrm{L}^{-1}$ each.

${ }^{d}$ Concentration employed $250 \mathrm{mg} \mathrm{L}^{-1}$.

e Concentration employed $125 \mathrm{mg} \mathrm{L}^{-1}$ each.

${ }^{f}$ Concentration employed $250 \mathrm{mg} \mathrm{L}^{-1}$.

${ }^{g}$ Concentration employed $125 \mathrm{mg} \mathrm{L}^{-1}$ each.

${ }^{\mathrm{h}}$ Concentration employed $200 \mathrm{mg} \mathrm{L}^{-1}$ citron oil and $50 \mathrm{mg} \mathrm{L}^{-1}$ carvarcol.

Time: the time (days) necessary to reach the cell load of $6.0 \log C F U \mathrm{~mL}^{-1}$ chosen as spoilage threshold.

A: maximum cellular density increase with respect to the initial cell load $(k)\left(\log C F U ~ g^{-1}\right)$.

$\mu$ max: maximum specific growth rate $\left(\left(\log \mathrm{CFU} \mathrm{g} \mathrm{g}^{-1}\right) /\right.$ days $)$.

$\lambda$ : latency time (lag time) (days).

$\mathrm{R}$ : correlation coefficient.

-unable to reach the spoilage value

Table 2: Gompertz parameters of yeast cell load dynamic equations in apples, stored at $6^{\circ} \mathrm{C}$, in relation to the applied dipping

higher cell concentrations can result in a visible blowing of the package. All the tested molecules, alone or in combination, significantly delayed the yeast growth $(\mathrm{p}<0.01)$. However, the most effective substances were hexanal when used at $250 \mathrm{mg} \mathrm{L}^{-1}$, citral and the mixture hexanal+ 2-(E)hexenal, both used at $125 \mathrm{mg} \mathrm{L}^{-1}$. Hexanal delayed the reaching of the spoilage threshold of about $10 \mathrm{~d}$ with respect to the control (Table 2), while the yeast cell loads in samples dipped with citral and the mixture of the two aldehydes never reached that limit.

A similar trend has been shown by LAB although their growth was delayed with respect to yeasts (data not shown). In fact, after $14 \mathrm{~d}$ of storage at $6^{\circ} \mathrm{C} \mathrm{LAB}$ reached levels of $5.0 \log \mathrm{CFU} \mathrm{g}{ }^{-1}$ only in the control samples, while in the other samples the LAB cell loads ranged between 1.0 and $2.7 \log \mathrm{CFU} \mathrm{g} \mathrm{g}^{-1}$. The efficacy of the tested antimicrobials to prolong the shelf-life of minimally processed fruit is well documented [33]. Belletti et al. [21] showed that citron essential oil doubled the time needed for the spoilage microflora to reach concentrations able to produce a perceivable spoilage during storage at $9^{\circ} \mathrm{C}$. A more pronounced delay of spoilage agents was obtained with citral which however evidenced some citotoxic effects on fruit tissue. Also the addition of hexanal and 2-(E)-hexenal in storage atmosphere of freshcut apple slices resulted in a positive effect on the product shelf-life because of the antimicrobial activity of these substances against naturally occurring spoilage species, also when deliberately inoculated at levels of $3 \log \mathrm{CFU} \mathrm{g}{ }^{-1}$. Moreover these molecules determined the enhancement of the aromatic properties, as well as the improvement of the original colour retention of the packed products. Also Siroli et al. [8] showed that the mixture hexanal+2-(E)-hexenal was one of the most effective in the prolongation of sliced apples packaged in MAP. However in these last samples the expiry date was mainly due to the changes of colour and texture parameters while yeasts never reached the spoilage threshold.

\section{Effects citron EO and natural antimicrobials on apple volatile molecules and electronic nose profiles}

In order to evaluate the effect of the compounds taken into consideration on the volatile molecule profiles as a function of storage time, the samples were analyzed by means of GC/MS-SPME and electronic nose. Although only the most significant molecules were reported in Table 3, the GC/MS-SPME allowed the identification of 45 molecules belonging to different chemical classes and provided specific volatile fingerprinting in relation to the antimicrobial agent used and to the storage time advancement. The supplemented antimicrobials and their detoxification greatly affected the volatile profile composition (Table 3). Actually, neral, geranial, nerol and geraniol characterized the samples supplemented with citral and citral in combination with citron oil. The latter sample showed the presence of high levels of limonene and terpinene, linalyl butyrate, $\beta$-mircene. The samples treated with citral was characterized also by citronellyl acetate and $\beta$-citronellol while hexanal, 2-(E)-hexenal, hexanol, and acetic acid hexyl esters were detected in the samples supplemented with hexanal and 2-(E)-hexenal. This sample showed a remarkable abundance (in term of peak area) of 2-hexen-1-ol, acetate. Hexanal and 2-(E)-hexenal showed higher levels in the control samples with respect to the samples treated with the same molecules indicating that their supplementation fastened the detoxification mechanisms adopted by tissues and naturally occurring microorganisms (Table 3). On the other hand, it has been demonstrated also for other aldehydes such as neral and geranial their reduction into nerol and geraniol as the first step of citral biotransformation by Penicilli into lower toxicity compounds [34]. Patrignani et al. [26] showed the increase during storage of such alcohols in fruit juices supplemented with citral over the storage; the authors attributed this phenomenon to the detoxifying mechanisms of spoilage yeasts. A similar detoxifying mechanism, i.e. reduction to the respective alcohols, was shown for six carbon aliphatic aldehydes. The samples supplemented with citron EO showed the presence of high amounts of monoterpenes and oxygenated monoterpenes, whose presence is well documented in citron EO. Carvacrol and thymol methyl ether were the main volatile molecules detected in the GC/MS-profiles of the samples added with carvacrol. A multivariate analysis using a heat map was performed in order to identify the molecules able to significantly contribute to the statistical discrimination among the samples, and five small clusters were obtained. The heat map underlined the role of the $\mathrm{EO}$ or the natural antimicrobials in grouping the samples (Figure 1). In particular, the sample submitted to the treatment with citron EO+carvacrol and stored up to $5 \mathrm{~d}$ grouped together (Cluster 2) and 
Citation: Siroli L, Patrignani F, Serrazanetti DI, Tabanelli G, Montanari C, et al. (2015) Potential of Natural Antimicrobials for the Production of Minimally Processed Fresh-Cut Apples. J Food Process Technol 6: 415. doi:10.4172/2157-7110.1000415

Page 6 of 9

\begin{tabular}{|c|c|c|c|c|c|c|c|c|c|c|c|c|c|c|c|c|c|c|c|c|c|c|c|c|}
\hline \multirow[b]{2}{*}{ Compounds } & \multicolumn{3}{|c|}{ Control a } & \multicolumn{3}{|c|}{$\begin{array}{l}\text { Citron oil } \\
+ \text { Citral }^{\mathrm{b}}\end{array}$} & \multicolumn{3}{|c|}{$\begin{array}{l}\text { Hexanal+ 2-(E)- } \\
\text { hexenal c }\end{array}$} & \multicolumn{3}{|c|}{ Citral ${ }^{d}$} & \multicolumn{3}{|c|}{$\begin{aligned} & \text { Citral } \\
+ \text { Hexanal } & \end{aligned}$} & \multicolumn{3}{|c|}{ Hexanal $^{f}$} & \multicolumn{3}{|c|}{$\begin{array}{l}\text { Citral + 2-(E)- } \\
\text { hexenal } 9\end{array}$} & \multicolumn{3}{|c|}{ Citron oil+ Carvacrol ${ }^{\mathrm{h}}$} \\
\hline & TO & T3 & T10 & TO & T3 & T10 & T0 & T3 & T10 & TO & T3 & T10 & T0 & T3 & T10 & TO & T3 & T10 & TO & T3 & T10 & T0 & T3 & T10 \\
\hline Ethyl acetate & 0.0 & 4.3 & 2.5 & 2.5 & 7.5 & 3.6 & 0.8 & 12.7 & 34.3 & 6.4 & 13.5 & 14.6 & 1.2 & 10.3 & 11.0 & 1.2 & 19.3 & 33.9 & 0.6 & 15.2 & 14.6 & 3.7 & 23.3 & 38.7 \\
\hline $\begin{array}{l}\text { Acetic acid, } \\
\text { isobutyl ester }\end{array}$ & 0.6 & 1.2 & 5.6 & 0.0 & 0.0 & 0.0 & 0.0 & 0.0 & 1.0 & 0.0 & 0.0 & 0.0 & 0.0 & 0.0 & 0.3 & 0.0 & 0.2 & 0.6 & 0.0 & 0.0 & 0.5 & 0.0 & 0.0 & 0.0 \\
\hline $\begin{array}{l}\text { Acetic acid, butyl } \\
\text { ester }\end{array}$ & 6.9 & 10.9 & 1.8 & 6.0 & 4.7 & 0.0 & 0.8 & 4.4 & 7.9 & 12.9 & 5.2 & 7.6 & 1.3 & 5.5 & 6.0 & 6.1 & 13.6 & 9.3 & 5.2 & 11.5 & 11.6 & 0.8 & 2.5 & 5.1 \\
\hline $\begin{array}{l}\text { 1-butanol, } \\
\text { 2-methyl-acetate }\end{array}$ & 11.0 & 11.5 & 12.3 & 5.6 & 4.0 & 0.0 & 1.1 & 1.4 & 4.8 & 23.7 & 11.8 & 5.2 & 4.3 & 5.5 & 1.7 & 15.3 & 27.5 & 3.6 & 5.9 & 10.0 & 2.8 & 2.6 & 4.1 & 4.3 \\
\hline $\begin{array}{l}\text { Acetic acid, hexyl } \\
\text { ester }\end{array}$ & 16.4 & 42.2 & 12.6 & 7.3 & 22.0 & 4.2 & 235.1 & 460.8 & 74.0 & 20.6 & 57.2 & 36.8 & 25.0 & 167.3 & 12.2 & 236.5 & 431.6 & 259.3 & 31.3 & 171.6 & 53.5 & 6.9 & 26.0 & 20.3 \\
\hline $\begin{array}{l}\text { 2-Hexen-1-ol, } \\
\text { acetate }\end{array}$ & 0.0 & 0.0 & 0.0 & 0.0 & 0.0 & 0.0 & 46.4 & 9.5 & 0.8 & 0.0 & 0.0 & 0.0 & 0.0 & 0.0 & 0.0 & 0.0 & 0.0 & 0.0 & 13.1 & 3.0 & 0.2 & 0.0 & 0.0 & 0.0 \\
\hline $\begin{array}{l}\text { Butanoic acid } \\
\text { methyl esters }\end{array}$ & 0.0 & 0.0 & 0.0 & 0.4 & 1.0 & 0.0 & 0.0 & 0.1 & 0.0 & 3.4 & 6.8 & 3.9 & 5.6 & 3.8 & 0.0 & 5.2 & 11.1 & 0.0 & 0.7 & 7.9 & 1.1 & 0.0 & 0.0 & 0.0 \\
\hline $\begin{array}{l}\text { Citronellyl } \\
\text { acetate }\end{array}$ & 0.0 & 0.0 & 0.0 & 0.3 & 5.4 & 1.9 & 0.0 & 0.0 & 0.0 & 1.4 & 9.5 & 11.1 & 1.5 & 10.2 & 0.4 & 0.0 & 0.0 & 0.0 & 1.2 & 21.8 & 4.0 & 0.0 & 0.0 & 0.0 \\
\hline Linalyl butyrate & 0.0 & 0.0 & 0.0 & 4.9 & 5.4 & 0.3 & 0.0 & 0.0 & 0.0 & 0.0 & 0.0 & 0.0 & 0.0 & 0.0 & 0.0 & 0.0 & 0.0 & 0.0 & 0.0 & 0.0 & 0.0 & 28.4 & 26.6 & 8.3 \\
\hline Total Esters & 34.9 & 70.0 & 34.7 & 26.9 & 50.0 & 10.1 & 284.2 & 489.0 & 122.8 & 68.5 & 104.1 & 79.2 & 38.9 & 202.6 & 31.6 & 264.3 & 503.3 & 306.6 & 58.0 & 240.9 & 88.2 & 42.4 & 82.5 & 76.6 \\
\hline Hexane & 0.0 & 0.0 & 0.0 & 0.0 & 0.0 & 0.0 & 0.0 & 0.0 & 0.0 & 0.0 & 0.0 & 7.5 & 0.0 & 0.0 & 0.0 & 0.0 & 0.3 & 0.0 & 6.4 & 0.0 & 0.0 & 0.0 & 0.0 & 0.0 \\
\hline$\beta$-myrcene & 0.0 & 0.0 & 0.0 & 0.4 & 0.3 & 0.0 & 0.0 & 0.0 & 0.0 & 0.0 & 0.0 & 0.0 & 0.0 & 0.0 & 0.0 & 0.0 & 0.0 & 0.0 & 0.0 & 0.0 & 0.0 & 4.1 & 3.6 & 2.0 \\
\hline Limonene & 0.4 & 1.7 & 1.4 & 38.6 & 28.3 & 2.6 & 0.0 & 0.4 & 0.9 & 1.0 & 1.3 & 0.9 & 1.7 & 0.5 & 0.0 & 0.7 & 0.2 & 0.0 & 0.5 & 1.1 & 0.3 & 213.0 & 203.1 & 124.8 \\
\hline a Terpinene & 0.0 & 0.0 & 0.0 & 19.7 & 19.0 & 1.5 & 0.0 & 0.0 & 0.0 & 0.0 & 0.0 & 0.0 & 0.0 & 0.0 & 0.0 & 0.0 & 0.0 & 0.0 & 0.0 & 0.0 & 0.0 & 155.5 & 126.9 & 72.1 \\
\hline Cymene & 0.0 & 0.0 & 0.0 & 13.3 & 3.1 & 0.0 & 0.0 & 0.0 & 0.0 & 0.0 & 0.0 & 0.0 & 0.0 & 0.0 & 0.0 & 0.0 & 0.0 & 0.0 & 0.0 & 0.0 & 0.0 & 35.0 & 66.3 & 55.2 \\
\hline$\beta$-pinene & 0.0 & 0.0 & 0.0 & 3.1 & 1.6 & 0.0 & 0.0 & 0.0 & 0.0 & 0.0 & 0.0 & 0.0 & 0.0 & 0.0 & 0.0 & 0.0 & 0.0 & 0.0 & 0.0 & 0.0 & 0.0 & 8.7 & 8.0 & 4.4 \\
\hline $\begin{array}{l}\text { thymol methyl } \\
\text { ether }\end{array}$ & 0.0 & 0.0 & 0.0 & 0.0 & 0.0 & 0.0 & 0.0 & 0.0 & 0.0 & 0.0 & 0.0 & 0.0 & 0.0 & 0.0 & 0.0 & 0.0 & 0.0 & 0.0 & 0.0 & 0.0 & 0.0 & 0.0 & 18.0 & 11.0 \\
\hline $\begin{array}{l}\text { Total } \\
\text { Hydrocarbons }\end{array}$ & 0.4 & 1.7 & 1.4 & 75.0 & 52.2 & 4.0 & 0.0 & 0.4 & 0.9 & 1.0 & 1.3 & 8.4 & 1.7 & 0.5 & 0.0 & 0.7 & 0.5 & 0.0 & 6.9 & 1.1 & 0.3 & 416.4 & 426.0 & 269.4 \\
\hline Nerol & 0.0 & 0.0 & 0.0 & 1.9 & 0.0 & 0.0 & 0.0 & 0.0 & 0.0 & 4.3 & 0.0 & 0.0 & 1.8 & 0.0 & 0.0 & 0.0 & 0.0 & 0.0 & 2.6 & 0.0 & 0.0 & 0.0 & 0.0 & 0.0 \\
\hline Geraniol & 0.0 & 0.0 & 0.0 & 1.8 & 0.0 & 0.0 & 0.0 & 0.0 & 0.0 & 5.0 & 0.0 & 0.0 & 1.4 & 0.0 & 0.0 & 0.0 & 0.0 & 0.0 & 2.2 & 0.0 & 0.0 & 0.0 & 0.0 & 0.0 \\
\hline Carvacrol & 0.0 & 0.0 & 0.0 & 0.0 & 0.0 & 0.0 & 0.0 & 0.0 & 0.0 & 0.0 & 0.0 & 0.0 & 0.0 & 0.0 & 0.0 & 0.0 & 0.0 & 0.0 & 0.0 & 0.0 & 0.0 & 27.4 & 15.5 & 0.0 \\
\hline$\beta$-citronellol & 0.0 & 0.0 & 0.0 & 39.6 & 58.3 & 33.4 & 0.0 & 0.0 & 0.0 & 63.7 & 144.3 & 81.1 & 44.8 & 64.8 & 4.7 & 0.0 & 0.0 & 0.0 & 42.4 & 72.1 & 21.5 & 6.5 & 6.0 & 0.0 \\
\hline Hexanol & 2.5 & 1.7 & 0.0 & 8.4 & 3.0 & 3.8 & 33.1 & 8.4 & 2.6 & 9.5 & 11.0 & 11.4 & 33.3 & 17.8 & 2.6 & 35.2 & 10.2 & 7.6 & 21.0 & 16.3 & 5.6 & 1.5 & 2.4 & 1.5 \\
\hline Ethanol & 0.6 & 0.9 & 0.0 & 12.0 & 10.8 & 6.1 & 11.0 & 8.9 & 8.0 & 14.0 & 12.2 & 10.3 & 11.5 & 10.3 & 4.9 & 14.1 & 12.0 & 8.7 & 10.8 & 11.5 & 7.4 & 14.5 & 14.1 & 9.3 \\
\hline Total Alcohols & 3.1 & 2.6 & 0.0 & 63.7 & 72.0 & 43.3 & 44.1 & 17.2 & 10.6 & 96.5 & 167.5 & 1029 & 92.8 & 92.9 & 12.2 & 49.3 & 22.2 & 16.3 & 79.0 & 99.9 & 34.5 & 49.9 & 38.0 & 10.8 \\
\hline Hexanal & 24.6 & 35.6 & 24.0 & 18.2 & 55.5 & 38.5 & 3.9 & 2.7 & 16.5 & 9.9 & 27.7 & 20.0 & 31.5 & 26.1 & 28.8 & 14.7 & 11.3 & 10.4 & 16.3 & 20.2 & 30.2 & 5.1 & 6.3 & 12.5 \\
\hline Neral & 0.0 & 0.0 & 0.0 & 2.9 & 0.0 & 0.0 & 0.0 & 0.0 & 0.0 & 48.7 & 1.0 & 0.0 & 2.0 & 0.0 & 0.0 & 0.0 & 0.0 & 0.0 & 8.1 & 0.0 & 0.0 & 0.0 & 0.0 & 0.0 \\
\hline Geranial & 0.0 & 0.0 & 0.0 & 3.7 & 0.5 & 0.0 & 0.0 & 0.0 & 0.0 & 48.4 & 1.9 & 0.0 & 3.3 & 0.0 & 0.0 & 0.0 & 0.0 & 0.0 & 8.2 & 0.0 & 0.0 & 0.0 & 0.0 & 0.0 \\
\hline 2-(E)-hexenal & 14.6 & 28.2 & 50.0 & 13.3 & 29.3 & 31.6 & 7.2 & 5.5 & 29.8 & 7.2 & 19.3 & 18.4 & 24.7 & 12.4 & 11.1 & 0.0 & 7.2 & 18.2 & 18.8 & 16.8 & 23.3 & 6.9 & 10.4 & 18.8 \\
\hline Total Aldehydes & 39.2 & 63.7 & 73.9 & 38.0 & 85.3 & 70.0 & 11.1 & 8.2 & 46.3 & 114.1 & 49.9 & 38.4 & 61.5 & 38.5 & 39.9 & 14.7 & 18.5 & 28.5 & 51.4 & 37.0 & 53.5 & 12.0 & 16.7 & 31.2 \\
\hline $\begin{array}{l}\text { Total } \\
\text { metabolites }\end{array}$ & 77.5 & 138.1 & 110.1 & 203.6 & 259.6 & 127.4 & 339.3 & 514.8 & 180.6 & 280.1 & 3229 & 228.9 & 194.9 & 334.5 & 83.6 & 329.0 & 544.6 & 351.4 & 195.3 & 378.9 & 176.5 & 520.6 & 563.1 & 388.1 \\
\hline
\end{tabular}

a Control was washed only with dipping solution ( $1 \%$ citric acid $+0.5 \%$ ascorbic acid)

${ }^{b}$ Concentration employed $125 \mathrm{mg} \mathrm{L}^{-1}$ each.

c Concentration employed $125 \mathrm{mg} \mathrm{L}^{-1}$ each

d Concentration employed $250 \mathrm{mg} \mathrm{L}^{-1}$

e Concentration employed $125 \mathrm{mg} \mathrm{L}^{-1}$ each.

${ }^{f}$ Concentration employed $250 \mathrm{mg} \mathrm{L}^{-1}$

${ }^{g}$ Concentration employed $125 \mathrm{mg} \mathrm{L}^{-1}$ each

${ }^{\mathrm{h}}$ Concentration employed $200 \mathrm{mg} \mathrm{L}^{-1}$ citron oil and $50 \mathrm{mg} \mathrm{L}^{-1}$ carvarcol.

Table 3: Volatile aroma compounds (expressed as Area $10^{-5}$ ) detected in apples treated with different dipping solutions during the storage time at $6^{\circ} \mathrm{C}$

a-terpinene, limonene and p-cymene contributed to the grouping. Hexanal clearly contributed to the formation of cluster 3 that grouped the samples added with hexanal immediately after packaging and after $10 \mathrm{~d}$ of storage; the sample supplemented with the mixture hexanal+2(E)-hexenal immediately after packaging as well as the sample supplemented with citral in mixture with hexanal or 2-(E)-hexenal after $3 \mathrm{~d}$ of storage. The samples of this cluster were characterised by the presence of acetic acid hexyl ester. The two samples of cluster 3 supplemented with citral were also characterized by the presence of $\beta$-citronellol; the latter molecule contributed to the formation of cluster 5, grouping the samples containing citral or citron EO alone or in mixture. Neral and geranial mainly characterised the samples added with citral analysed immediately after the supplementation. The control samples were distributed in two subclusters of cluster 4 that included samples with citral $+2-(E)$-hexenal, hexanal and 2-(E)-hexenal and citron+citral after $10 \mathrm{~d}$ of storage. This cluster was characterized by the presence of 2-(E)-hexenal, hexanal and ethyl acetate. The samples supplemented with citron-citral and stored for $10 \mathrm{~d}$ showed the highest similarity to the controls analysed immediately after the packaging. (Cluster 1) comprised the samples supplemented with hexanal and 


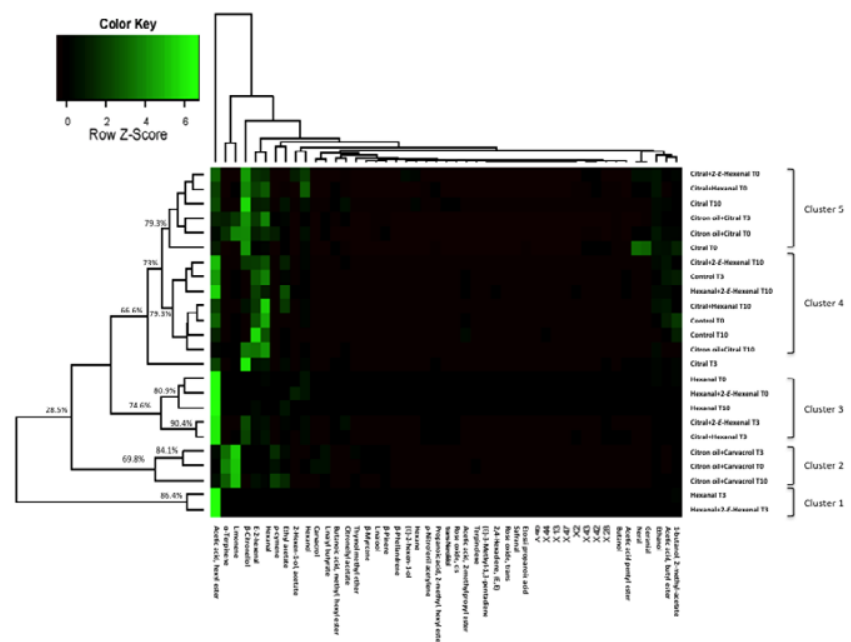

Figure 1: Heat map of correlations between metabolites produced during the storage of apples treated with citron essential oil, natural antimicrobials and their combinations. Each square represents the Spearman's correlation.

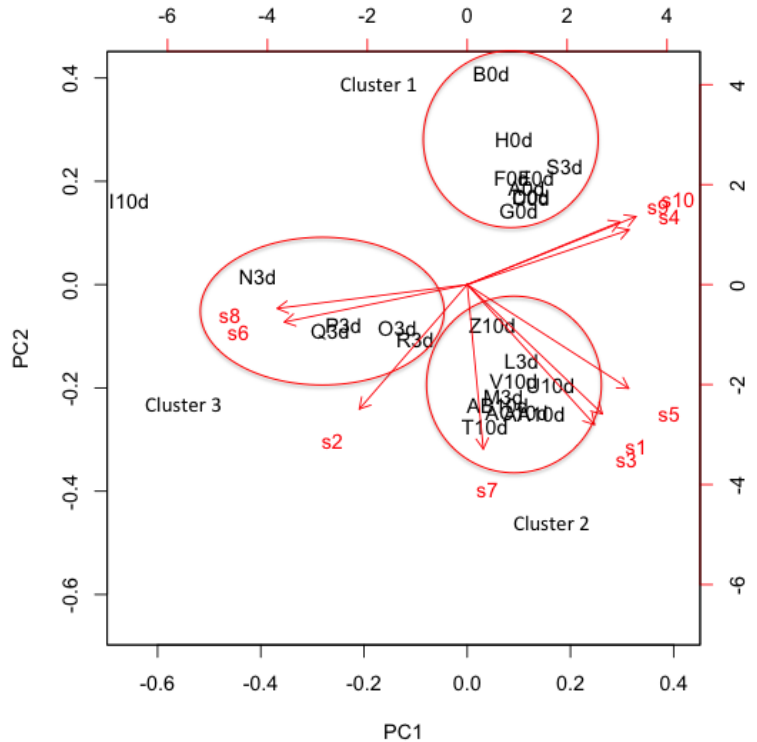

Figure 2: Projection of the scores (different apples treated with citrus essential oil, natural antimicrobials and their combination) and loadings (sensors) on the factor-plane (1x2). PC1 and PC2 explained $57.4 \%$ and 26.9 of the total variance respectively.

Cluster 1: A0d (control $0 \mathrm{~d}$ ), B0d (citral $0 \mathrm{~d}$ ), COd (hexanal $0 \mathrm{~d}$ ), DOd (citral+hexanal $0 \mathrm{~d}$ ), E0d (citral+citron oil $0 \mathrm{~d}$ ), FOd (citral+2-(E)-hexenal $0 \mathrm{~d}$ ), GOd (citron oil+carvacrol $0 \mathrm{~d}$ ), HOd (hexanal+2-(E)-hexenal $0 \mathrm{~d}$ ), S3d (control $3 \mathrm{~d}$ ). Cluster 2: T10d (citral $10 \mathrm{~d}$ ), U10d (hexanal $10 \mathrm{~d}$ ), V0d (citral+hexanal $10 \mathrm{~d}$ ), Z10d (citral+citron oil $10 \mathrm{~d}$ ), AA10d (citral+2-(E)-hexenal $10 \mathrm{~d})$, AB10d (citron oil+carvacrol $10 \mathrm{~d}$ ), AC10d (hexanal+2-(E)-hexenal $10 \mathrm{~d}$ ), L3d (citral $3 \mathrm{~d}$ ), M3d (hexanal $3 \mathrm{~d}$ ).

Cluster 3: N3d (citral+hexanal $3 d$ ), O3d (citral+citron oil $3 d$ ), P3d (citral+2-(E)hexenal 3 d), Q3d (citron oil+carvacrol $3 d$ ), R3d (hexanal+2-(E)-hexenal $3 d$ ), I10d (control $10 \mathrm{~d}$ ).

hexanal+2-(E)-hexenal after $3 \mathrm{~d}$ of storage, with acetic acid hexyl ester as the unique discriminating molecule. The samples supplemented with citral after $3 \mathrm{~d}$ of storage did not group in any cluster but was near to cluster 4 with a similarity percentage of $66.6 \%$; these samples were characterized by the highest abundance of $\beta$-citronellol. The storage time did not contribute significantly to the clustering, probably because of the different detoxification rate and patterns of the supplemented substances, in their turns dependent on microbial composition (in terms of species and strains) and growth rate. Moreover the volatile molecule profiles reflected also the metabolisms of apple tissue. In this direction Gutierrez et al. attributed the increases of same terpenic molecules over storage of lettuce and carrot supplemented with oregano and thyme to microbial metabolism and to the tissue synthesis throughout mevalonic acid.

The data obtained with electronic nose were subjected to a principal component analysis in order to outline the differences among the samples detected by the 10 sensors of the instrument. All the samples were mapped in the space spanned by the first two principal components PC1 versus PC2. The score and loading plot, reported in Figure 2, show the clustering of the samples according mainly to storage time. Three different clusters were evident in the PCA plot. The first cluster grouped the samples analyzed immediately after packaging, independently of the presence of natural antimicrobials. The second group accounted for the samples stored for $10 \mathrm{~d}$ and samples stored for $3 \mathrm{~d}$ supplemented with citral or hexanal, while the third cluster contained all the remaining samples stored for $3 \mathrm{~d}$. Exception was represented by the $3 \mathrm{~d}$-control samples belonged to the first cluster. All the samples, except those of the cluster 3 (containing the samples analysed after $3 \mathrm{~d}$ of storage), were not discriminated on the basis of $\mathrm{PC} 1$ ( $57.4 \%$ of variance was captured by the first PC), while were grouped in two clusters on the basis of PC2 (26.9\% of variance) that captured most of the variation among the three considered storage time. The cluster 3 differed by the other samples on the basis of PC1. In particular, the sensors 8 and 6, detecting alcohols and hydrocarbons, respectively, accounted for this clusterization. Sensor 9, a quite aspecific sensor, characterized the cluster 1 while sensors 1,3 and 5, more responsive for aromatic compounds, defined the Figure $3 b$ (Cluster 2). Sado et al. [35] in a study aimed to evaluate the sensitiveness of electronic nose to discriminate different chemical classes, showed that response of sensors 9 and 2 have a similar responsiveness while the sensors 1,3 and 5 had an inverse responsiveness to the analyzed substances. This different response could contribute to the sample clustering. The data clearly indicate that the addition of the chosen compounds did not affect significantly the electronic nose profiles. In fact, the clusterization was based mainly on storage time except for the samples added with citral or hexanal stored for $3 \mathrm{~d}$ that clusterized with the $10 \mathrm{~d}$-stored samples. Probably in these samples this behaviour can be attributed to the delayed yeast growth, as shown by the Gompertz parameters. On the other hand, the used concentrations were chosen on the basis of preliminary trials aimed to balance the antimicrobial activity and the sensorial impact of the product.

\section{Effects of Citron EO and natural antimicrobials on colour and texture of fresh-cut apple slices}

As reported in Figure 3a, dipping treatments with essential oil and natural antimicrobials promoted immediately a modification of the achromatic component of fresh-cut apples colour, corresponding to a decrease of $L^{*}$ in the range of 1.5-3.5 units. According to Fltcher [36], the human eyes can recognize $\Delta \mathrm{L}^{*}$ differences higher than three units; the $\mathrm{L}^{*}$ decrease promoted by the treatments investigated is around this value. Until the fourth $\mathrm{d}$ of storage, control sample showed the highest $L^{*}$ values, with a progressively decreasing trend until the end of the experiment, as a consequence of enzymatic browning advancement. After four $\mathrm{d}$ of storage, among investigated treatments, citral+citron 


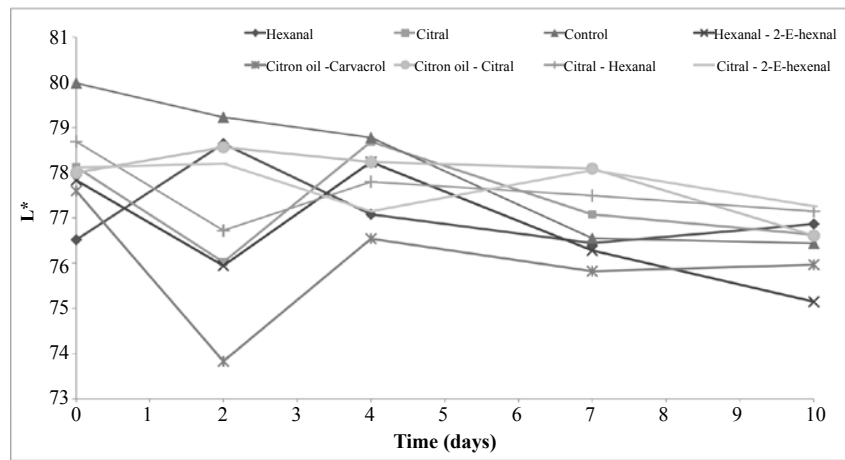

Figure 3a: Evolution of luminosity, $L^{*}$ of apples treated with citron essential oil, natural antimicrobials and their combinations during storage time.

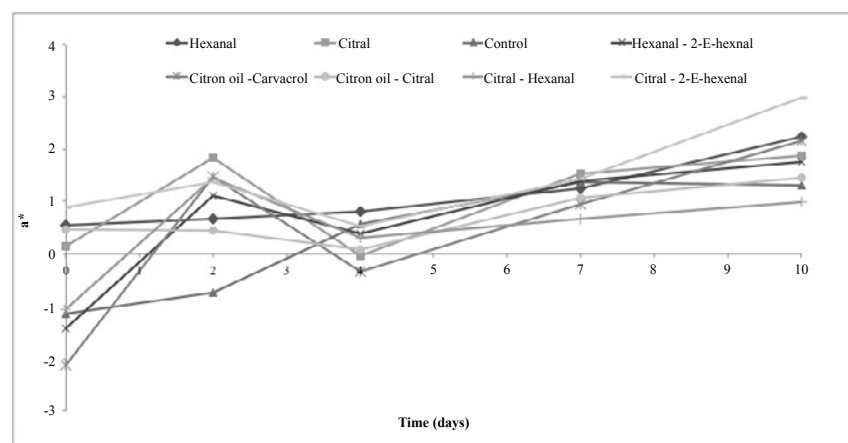

Figure 3b: Evolution of red index, $\mathrm{a}^{*}$, of apples treated with citron essential oil natural antimicrobials and their combinations during storage time.

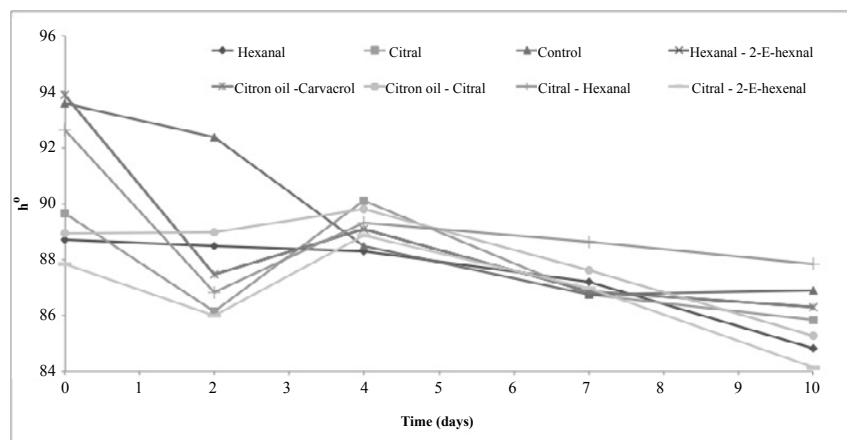

Figure 3c: Evolution of hue angle, $h^{*}$, of apples treated with citron essential oil natural antimicrobials and their combinations during storage time.

EO, citral+2-(E)-hexenal, citral+hexanal and citral $250 \mathrm{mg} \mathrm{L}^{-1}$ evidenced the highest levels of $L^{*}$, showing a positive effect on the inhibition of $\mathrm{L}^{*}$ decrease. Treatments with hexanal $250 \mathrm{mg} \mathrm{L}^{-1}$, citral $250 \mathrm{mg}$ $\mathrm{L}^{-1}$, citral+citron EO and citral $+2-(E)$-hexenal caused an immediate increase on the red index $\left(a^{*}\right)$ of apple slices colour (Figure $3 b$, ), while hexanal $+2-(E)$-hexenal, citron $\mathrm{EO}+$ carvacrol and citral+hexanal samples showed initial values of $\mathrm{a}^{*}$ very similar to control sample. After two $d$ of storage, all treated samples showed significantly higher values of $\mathrm{a}^{\star}$ compared to the control, reaching similar values at the fourth $\mathrm{d}$ of refrigeration. Among investigated treatments, during the second part of storage, citral+hexanal permitted to maintain the lowest $\mathrm{a}^{*}$ values on apple slices surface. As far as hue angle $\left(\mathrm{h}^{\circ}\right)$ (Figure $3 \mathrm{c}$ ), treatments with citrus EO+carvacrol and citral+hexanal seemed not to influence this parameter, but after two d of storage control sample showed a $\mathrm{h}^{\circ}$ value very similar to the initial one, while all treated samples evidenced a fast decrease in the first part of the storage period. From the fourth $\mathrm{d}$ to the end of the experiment, the decreasing trend of $\mathrm{h}^{\circ}$ was very similar for all the samples investigated excluded sample citral+hexanal, that showed the highest $h^{\circ}$ values after respectively height and ten $\mathrm{d}$ of storage.

The initial browning caused by citral is in accordance with the data of Belletti et al. [21] who observed citotoxic effect on apple slices in fruit salad in syrup, when the terpenic molecule was used at concentration of $125 \mathrm{mg} \mathrm{L}^{-1}$. Probably in our experimental conditions, the negative effects of citral was reduced when in combination with hexanal. On the other hand, the positive effect of hexanal on apple colour maintenance has been already observed. To the conversion of hexanal to hexanol was attributed the key to understanding its effect on browning delay. In fact, the aliphatic alcohols are regarded as inhibitors of polyphenol oxidase [37]. As a consequence of dipping treatment, only sample citral $250 \mathrm{mg}$ $\mathrm{L}^{-1}$ showed higher value of firmness compared with the control, while the treatment with citral+citron EO caused the maximum softening. Citral $250 \mathrm{mg} \mathrm{L}^{-1}$ effect was lost after just two d of storage (Figure 4). As expected, generally during storage, apple slices firmness decreased for all samples investigated in a very similar way. Among them, only the sample hexanal+2-(E)-hexenal maintained higher firmness values compared with the control for all the storage period investigated.

\section{Conclusions}

The effectiveness of citron oil and natural antimicrobial compounds to delay the spoilage agents of minimally processes apples was demonstrated in this research. The sole use of the antimicrobials considered delayed the reaching of the yeast spoilage threshold in a range of 3-10 d with respect to the controls. Among the tested conditions, citral and hexanal+2-(E)-hexenal were the most effective to inhibit the yeast growth that did not attain the spoilage threshold within $21 \mathrm{~d}$ of storage and to maintain the texture and colour parameters during the prolonged storage. Although all the compounds used determined a specific GC/MS-SPME volatile molecule profile, they did not affect the electronic nose profiles of the samples that clusterized mainly on the basis of storage time. Exceptions were represented by the samples added with citral or hexanal stored for $3 \mathrm{~d}$ that clusterized with $10 \mathrm{~d}$-stored samples, demonstrating that during this storage time no significant modifications appeared in the electronic nose profiles of these samples. Physical analysis results showed that generally until fourth-seven $\mathrm{d}$ of storage control sample better maintained its initial

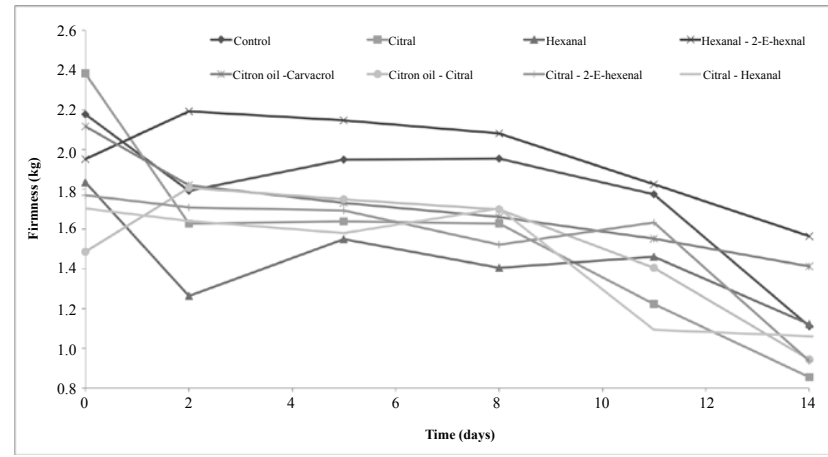

Figure 4: Evolution of firmness (kg.g) of apples treated with citron essential oil, natural antimicrobials and their combinations during storage time. 
Citation: Siroli L, Patrignani F, Serrazanetti DI, Tabanelli G, Montanari C, et al. (2015) Potential of Natural Antimicrobials for the Production of Minimally Processed Fresh-Cut Apples. J Food Process Technol 6: 415. doi:10.4172/2157-7110.1000415

colour and texture characteristics. The beneficial effects of dipping with essential oils solutions become noticeable in the second part of the storage period, suggesting the potential use of these treatments for long storage of fresh-cut apples packaged in ordinary atmosphere.

\section{Acknowledgment}

This experimental research was supported by the national project AGERSTAY FRESH 20102370.

\section{References}

1. Abadias M, Alegre I, Usall J, Torres R, Vinas I (2011) Evaluation of alternative sanitizers to chlorine disinfection for reducing foodborne pathogens in fresh-cut apple. Postharvest Biol Tec 59: 289-297.

2. Thunberg RL, Tran TT, Bennett RW, Matthews RN, Belay N (2002) Microbia evaluation of selected fresh produce obtained at retail markets. J Food Protect 4: 677-682.

3. Lanciotti R, Belletti N, Patrignani F, Gianotti A, Gardini F, et al. (2003) Application of Hexanal, (E)-2-Hexenal, and Hexyl Acetate To Improve the Safety of Fresh-Sliced Apples. J Agri Food Chem 51: 2958-2963.

4. Rojas-Grau MA, Roybaudi-Massilia RM, Soliva-Fortuny RC, Avena-Bustillos RJ, McHugh TH, et al. (2007) Apple puree-alginate edible coating as carrier of antimicrobial agents to prolong shelf-life of fresh-cut apples. Postharvest Biol Tec 45: 254-264

5. Abadias M, Canamas TP, Asensio A, Anguera M, Vinas I (2006) Microbia quality of commercial 'Golden Delicious' apples throughout production and shelf-life in Lleida (Catalonia, Spain). Int J Food Microbiol 108: 404-409.

6. Alegre I, Abadias M, Anguera M, Oliveira M, Vinas I (2010) Factors affecting growth of foodborne pathogens on minimally processed apples. Food Microbio 27: 70-76.

7. Lanciotti R, Gianotti A, Patrignani F, Belletti N, Guerzoni ME, et al. (2004) Use of natural aroma compounds to improve shelf-life and safety of minimally processed fruits. Trends Food Sci Technol 15: 201-208.

8. Siroli L, Patrignani F, Serrazanetti DI, Tabanelli G, Montanari C, et al. (2014) Efficacy of natural antimicrobials to prolong the shelf-life of minimally processed apples packaged in modified atmosphere. Food Control 46: 403-411.

9. Allende A, Selma M V, López-Gálvez F, Villaescusa R, Gil Ml (2008) Role of commercial sanitizers and washing systems on epiphytic microorganisms and sensory quality of fresh cut escarole and lettuce. Postharvest Biol Tec 49 : $155-163$

10. López-Gálvez F, Allende A, Selma MV, Gil MI (2009) Prevention of Escherichia coli cross-contamination by different commercial sanitizers during washing of fresh-cut lettuce. Int J Food Microbiol 133: 167-171.

11. Gutierrez J, Bourke P, Lonchamp J, Barry-Ryan C (2009) Impact of plant essential oils on microbiological, organoleptic and quality markers of minimally processed vegetables. Innov Food Sci Emerg 10: 195-202.

12. Vandekinderen I, Devlieghere F, De Meulenaer B, Ragaert P, Van Camp J (2009) Decontamination strategies for fresh-cut produce. Stewart Postharvest Rev 5: $1-8$

13. De Azeredo GA, Stamford TLM, Nunes PC, Neto NJG, de Oliveira MEC (2011) Combined application of essential oils from Origanum vulgare $\mathrm{L}$. and Rosmarinus officinalis L. to inhibit bacteria and autochthonous microflora associated with minimally processed vegetables. Food Res Int 44: 1541-1548.

14. Utama IMS, Willis RBH, Ben-Yehoshua, S, Kuek C (2002) In vitro efficacy of plant volatiles for inhibiting the growth of fruit and vegetable decay microorganisms. J Agri Food Chem 50: 6371-6377.

15. Delaquis PJ, Stanich K, Girard B, Mazza G (2002) Antimicrobial activity of individual and mixed fractions of dill, cilantro, coriander and eucalyptus essential oils. Int J Food Microbiol 74: 101-109.

16. Belletti N, Ndagijimana M, Sisto C, Guerzoni ME, Lanciotti R, et al. (2004) Evaluation of the antimicrobial activity of citrus essences on Saccharomyces cerevisiae. J Agri Food Chem 52: 6932-6938.

17. McNeil M, Facey P, Porter R (2011) Essential oils from the Hyptis genus - A review (1909-2009) Nat Prod Com 6: 1775-1796.

18. Sagdic O, Ozturk I, Tornuk F (2013) Inactivation of non-toxigenic and toxigenic Escherichia coli $\mathrm{O} 157: \mathrm{H} 7$ inoculated on minimally processed tomatoes and cucumbers: Utilization of hydrosols of Lamiaceae spices as natural food sanitizers. Food Control 30: 7-14

19. Vazquez BI, Fente C, Franco C, Vazquez MJ, Cepeda A (2001) Inhibitory effects of eugenol and thymol on Penicillium citrinum strains in culture media and cheese. Int J Food Microbiol 67: 157-163.

20. Wuryatmo E, Klieber A, Scott ES (2003) Inhibition of citrus postharvest pathogens by vapor of citral and related compounds in culture. J Agric Food Chem 51: 2637-2640.

21. Belletti N, Lanciotti R, Patrignani F, Gardini F (2008) Antimicrobial efficacy of citron essential oil on spoilage and pathogenic microorganisms in fruit-based salads. J Food Sci 73: M331-338

22. Gardini F, Lanciotti R, Guerzoni ME (2001) Effect of (E)-2-hexenal on the growth of Aspergillus flavus in relation to its concentration, temperature and water activity. Lett Appl Microbiol 33: 50-55.

23. Corbo MR, Lanciotti R, Gardini F, Sinigaglia M, Guerzoni ME (2000) Effects of hexanal, (E)-2-hexenal, and storage temperature on shelf life of fresh sliced apples. J Agri Food Chem 48: 2401-2408.

24. Serrano M, Martínez-Romero D, Guillén F, Valverde JM, Zapata PJ, et.al., (2008) The addition of essential oils to MAP as a tool to maintain the overal quality of fruits. Trends Food Sci Tech 19: 464-471.

25. Jacxsens L, Devlieghere F, Ragaert P, Vanneste E, Debevere J (2003) Relation between microbiological quality, metabolite production and sensory quality of equilibrium modified atmosphere packaged fresh-cut produce. Int J Food Microbiol 83: 263-280.

26. Patrignani F, Tabanelli G, Siroli L, Gardini F, Lanciotti R (2013) Combined effects of high pressure homogenization treatment and citral on microbiological quality of apricot juice. Int J Food Microbiol 160: 273-281.

27. Sado Kamden SL, Ndagijimana, Vannini L, Guerzoni ME (2007) Differentiation of fresh seafood products and storage time using an electronic nose: features selection for data analysis. Italian Jf Food Sci, (SLIM 2006): 393-399.

28. McGuire RG (1992) Reporting of objective color measurements. Hort Sci 27 1254-1255.

29. Zwietering MH, Jongenburger I, Rombouts FM, Van 'T Riet (1990) Modelling of the bacterial growth curve. Applied and Environmental Microbiology 56: 18751881.

30. Serrazanetti DI, Ndagijimana M, Sado SL, Corsetti A, Vogel RF, et al. (2011) Acid stress-mediated metabolic shift in Lactobacillus sanfranciscensis LSCE1. Appl Environmental Microbiol 77: 2656-2666.

31. Helander IM, von Wright A, Matilla-Sandholm TM (1997) Potential of lactic acid bacteria and novel antimicrobials against Gram-negative bacteria. Trends Food Sci Technol 8: 146-150.

32. Patrignani F, Vannini L, Kamdem SLS, Lanciotti R, Guerzoni ME (2009) Effect of high pressure homogenization on Saccharomyces cerevisiae inactivation and physico-chemical features in apricot and carrot juices. Int J Food Microbiol 136: 26-31.

33. Patrignani F, lucci L, Belletti N, Gardini F, Guerzoni ME, et al. (2008) Effects of sub-lethal concentrations of hexanal and 2-(E)-hexenal on membrane fatty acid composition and volatile compounds of Listeria monocytogenes, Staphylococcus aureus, Salmonella enteritidis and Escherichia coli. Int J Food Microbiol 123: 1-8

34. Esmaeili A, Tavassoli A (2010) Microbial transformation of citral by Penicillium sp. Acta Biochim Pol 57: 265-268.

35. Sado Kamden SL, Serrazanetti D, Ndagijimana M, Belletti N, Essia-Ngang JJ (2010) Assessment of meat spoilage bacteria by the use of electronic nose. 22 $2^{\text {nd }}$ International ICHFMH symposium Food micro 2010.

36. Fltcher DL (1999) Broiler Breast Meat Color Variation, pH, and Texture. Poultry Sci 78: 1323-1327.

37. Valero E, Varon R, Garcia-Carmona F (1990) Inhibiton of grape polypheno oxidase by several aliphatic alcohols. J Agri Food Chem 38: 1097-1103. 